\title{
Stiffness and Damping of Epoxy Granite
}

\author{
Deepak D. Ubale, Raviraj V. Nimbalkar, Vivek R. Chavan
}

\begin{abstract}
The productivity and accuracy of machine tools now became most significant as the cutting conditions changes continuously. Therefore to withstand against these cutting conditions the machine tool structural material must have higher stiffness and damping. This review deals with various research works to study the stiffness and damping of epoxy granite or polymer concrete. It is reported that the epoxy granite shows improved damping and high strength to weight ratio than that of conventional machine tool structures of steel and cast iron.
\end{abstract}

\section{Keywords: Epoxy Granite, Stiffness, Damping factor}

\section{INTRODUCTION}

The research in the field of alternative structural materials for machine tools is increased in last few decades. The productivity and accuracy of machine tool became most significant due to continuously changing cutting conditions. The productivity and accuracy is adversely affected by vibrations in machine tool. These vibrations are categorized into two types: Forced vibrations and Self-excited vibrations. The forced vibrations are due to unbalance rotating parts or intermittent engagement of work piece and cutter. Such vibrations can cause waviness in machined surface of work piece. Forced vibrations are intense at resonance condition. The self-excited vibrations occur when there is change in cutting process such as increase in metal removal rate. This type of vibrations is referred as Chatter. The chatter causes unacceptable finish of work piece and reduces the life of machine and tool which results into increased cost of manufacturing. These vibrations must be suppressed to have productivity with high accuracy. Otherwise these vibrations affect surface quality of work piece machined and reduce the life of machine and cutting tool. To control these vibrations structural materials of high stiffness and better damping must be used for machine tool structure. The researchers in the field of machine tool are always in search of alternative materials for machine tool structure which offers high stiffness and better damping. This review paper deals with various researches with respect to the stiffness and damping of developed materials for machine tool structure over last few decades. Any system which vibrates has three elements namely 1.Mass of system (m), 2. Stiffness of material used for system $(\mathrm{k})$ and 3. Damping (Material Damping) of system ( $\zeta$ ). Mass depends on density of material used and parts geometry of system. Stiffness depends on Young's modulus (E), Shear modulus (G) (in some cases it depends on one modulus), parts geometry and nature of loading. To withstand high dynamic forces at higher cutting speeds and feeds the machine tool structure should have high stiffness. The dynamic behavior of any vibratory system mostly depends upon its damping capacity. Higher the damping more is the energy dissipated from vibrating system per cycle. Thus vibrations are suppressed at faster rate.

It was found that two methods were used for determination of damping factor $(\zeta)$.

1. Logarithmic decrement method

$$
\delta=\ln \left(\frac{\mathrm{x} 1}{\mathrm{x} 2}\right)=\frac{2 \pi \zeta}{\sqrt{1-\zeta^{2}}}
$$

Where, $\mathrm{X}_{1}$ and $\mathrm{X}_{2}$ are any two successive amplitudes, $\delta$ is logarithmic decrement.

2. Half-Power bandwidth method

$$
\zeta=\frac{\mathrm{f} 2-\mathrm{f} 1}{\mathrm{fn}}
$$

Where ' $f_{n}$ ' is the natural frequency, $f_{1}$ and $f_{2}$ are frequencies at half power bandwidth.

Table I shows the mechanical properties of structural materials used for machine tool structure such as steel, cast iron and epoxy granite. The strength to weight ratio (Young's modulus to Density) of steel is about twice than that of cast iron. The strength to weight ratio of epoxy granite is greater than cast iron. The loss factor represents degree of material damping. The loss factor of epoxy granite is 10 times higher than steel.

Table I Mechanical Properties of structural materials

\begin{tabular}{|c|c|c|c|}
\hline Material & $\begin{array}{c}\text { Density } \\
\left(\mathbf{K g} / \mathbf{m}^{\mathbf{3}}\right)\end{array}$ & $\begin{array}{c}\text { Young's Modulus } \\
(\mathbf{M P a})\end{array}$ & $\begin{array}{c}\text { Order of Loss factor } \\
(\boldsymbol{\eta}=\mathbf{2 \zeta})\end{array}$ \\
\hline Steel & 7850 & 210 & $10^{-3}$ \\
\hline Cast Iron & 7150 & 100 & $10^{-2}$ \\
\hline Epoxy Granite & 2100 & 30 & $10^{-2}$ \\
\hline
\end{tabular}

Revised Manuscript Received on February 05, 2020.

* Correspondence Author

Deepak D. Ubale*, Department of Mechanical Engineering, D.I.E.T., Satara, India, ubaledd@gmail.com

Raviraj V. Nimbalkar, Department of Mechanical Engineering, D.I.E.T., Satara, India, rajvickyn@gmail.com

Vivek R. Chavan, Department of Mechanical Engineering, D.I.E.T., Satara, India, chavanvrc@gmail.com

(C) The Authors. Published by Blue Eyes Intelligence Engineering and Sciences Publication (BEIESP). This is an open access article under the CC BY-NC-ND license (http://creativecommons.org/licenses/by-nc-nd/4.0/) 


\section{Stiffness and Damping of Epoxy Granite}

\section{METHODOLOGY}

\section{Material Characterization}

A lot of research works reported was based on characterization of mechanical properties of developed materials referred as epoxy granite or polymer concrete. The epoxy granite is homogeneous mixture of a polymeric resin and aggregates in coarse and fine forms. The polymeric resins that are commonly used polyester resin, epoxy resin, vinyl ester resin etc. Polyester resins are the most commonly used resin because of their low cost, easy availability, and good mechanical properties. The crushed stone, quartz, granite and gravel are used as aggregates.

\section{Fillers (Aggregates)
(Granite/(Quartz etc.) $\underset{\text { (Polyester/Epoxy) }}{\text { Resin }} \backsim \begin{gathered}\text { Polymer Concrete } \\ \text { (Epoxy Granite) }\end{gathered}$}

Fig. 1. Process of Epoxy Granite

The damping tests were performed to investigate the damping on polymer concrete samples. These samples comprised of $20 \%$ polyester resin and quartz fillers (in five different compositions) by weight. The observed critical damping ratio of polymer concrete was approximately four to seven times greater than the cast iron [1]. The composite samples of $80 \%$ of granite and $20 \%$ of epoxy resin by weight were tested for damping behavior by the logarithmic decrement method. It was found that damping properties were approximately three times greater than grey cast iron [2]. The damping behavior was examined at equal stiffness of epoxy granite, cast iron and steel. The epoxy granite specimen of $88 \%$ of granite and $12 \%$ of epoxy resin by weight was prepared to perform the damping test. It was found that the epoxy granite provides high damping ratio and large mass reduction in comparison with the steel and cast iron at equal stiffness [3].

The cast iron particles as filler material in the proportions of $5 \%, 10 \%$, and $15 \%$ added to the epoxy granite. The dynamic analysis tests were performed on specimens to determine damping factors by half power method from the frequency response curves. The higher damping factor was observed for specimen of $5 \%$ cast iron particles and epoxy content more than $20 \%$. It was also observed that the damping factor reduces if cast iron fillers percentage is more than 5\% [4]. To improve tensile strength and Young's modulus, glass fibres were used in polymer concrete because of its higher tensile strength. The glass fibre reinforced polymer concrete (GFRPC) is the mixture of glass fibre and polymer concrete. The damping tests were performed on GFRPC specimens to examine damping behavior. It was observed that as epoxy resin increases there is increase in damping ratio of GFRPC. It is because of damping ratio of epoxy resin is higher than granite. It was found that as glass fibre quantity increases in GFRPC its damping ratio increases. The maximum value of damping ratio obtained when glass fibre length was $20 \mathrm{~mm}$ [5].

The logarithmic decrement and half-power bandwidth method are not consistent statistically as two and three measurement points are considered respectively. The complex modulus of polymer concrete developed was determined and compared with grey cast iron materials. The polymer concrete developed had $10 \mathrm{~mm}$ aggregate (basalt and quartzite) and $10 \%$ epoxy resin by weight. To determine damping, 2500 measured points were considered and Nelder-Mead minimization algorithm was used for curve fitting. It was found that the developed polymer concrete has a higher damping in large range of frequencies than grey cast iron [6].

\section{Structure Redesign}

Some of the research studies reported was based on the structure redesign or modification of existing machine tool structure in order to improve stiffness and damping. This technique is generally passive strategy of vibration control.

The bed of micro lathe was fabricated in epoxy granite having same stiffness same as that of cast iron bed. The dimensions of epoxy granite bed were determined by analytical and finite element method. To manufacture the epoxy granite bed $88 \%$ granite (in coarse, medium and fine form) and $12 \%$ resin by weight was used. It was observed that the damping ratio of epoxy granite bed is improved by 2.2 times greater than cast iron bed. The weight of the epoxy granite lathe bed in comparison with cast iron bed was reduced by $38.64 \%$ for same stiffness [7].

The welded steel structure or steel reinforcements were used with epoxy granite structure for both further improvement of stiffness and damping. The polymer concrete bed with welded steel structure was developed for a high-speed gantry type milling machine. The composition of polymer concrete used contains gravel of $60 \%$, sand $30 \%$ and polyester $10 \%$ by weight. It was found that damping factor is $2.93 \%-5.69 \%$ larger than conventional structure over wide range of frequency from the impact dynamic test [8].

The few studies reported was based the proposed finite element models of in earlier stage of redesign. The design of the machine tools made of artificial granite material verified through the Finite Element approach. Also prototype machine of same was fabricated for experiment to realize the feasibility of granite in the machine tool. The obtained minimum dynamic stiffness of the granite model was $0.5-1.3$ times higher than that of casting machine [9]. The finite element model of epoxy-granite-made vertical machining centre column with steel reinforcement was proposed to improve its static and dynamic characteristics. The FE model of equivalent static stiffness and natural frequencies of about $12-20 \%$ higher than cast iron structure can be used alternative for the existing column to have higher structural damping and equivalent or higher static stiffness [10]. 
Table II Brief summary of literature survey

\begin{tabular}{|c|c|c|c|}
\hline Author & Resin & Filler & Findings \\
\hline S. Orak & $20 \%$ Polyester resin & Quartz fillers & $\begin{array}{l}\text { Damping ratio of polymer concrete } \\
\text { was approximately four to seven } \\
\text { times greater than the cast iron }\end{array}$ \\
\hline 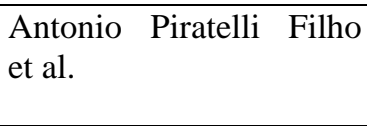 & 20\% Epoxy resin & Granite & $\begin{array}{l}\text { Damping properties approximately } \\
\text { three times greater than grey cast } \\
\text { iron }\end{array}$ \\
\hline A. Selvakumar et al. & 12\% Epoxy resin & Granite & $\begin{array}{l}\text { High damping ratio and large mass } \\
\text { reduction } \\
\text { as compared to steel and cast iron } \\
\text { without compromise in stiffness }\end{array}$ \\
\hline S. S. Balakrishna et al. & $\begin{array}{c}\text { More than } 20 \% \text { Epoxy } \\
\text { resin }\end{array}$ & $\begin{array}{l}5 \% \text { Cast iron } \\
\text { particles and } \\
\text { Granite }\end{array}$ & Higher damping factor \\
\hline Wenfeng Bai et al. & 16\% Epoxy Resin & $\begin{array}{l}\text { Glass fibre }(20 \\
\text { mm) and Granite }\end{array}$ & $\begin{array}{l}\text { As glass fibre increases damping } \\
\text { ratio increases }\end{array}$ \\
\hline Cortes F. et al. & 10 \% Epoxy Resin & $\begin{array}{l}\text { Basalt and } \\
\text { Quartzite }\end{array}$ & $\begin{array}{l}\text { Higher damping in large range of } \\
\text { frequencies than grey cast iron }\end{array}$ \\
\hline A. Selvakumar et al. & 12\% Epoxy Resin & Granite & $\begin{array}{l}\text { Damping ratio improved by } 2.2 \\
\text { times and weight reduced by } 38.64 \\
\% \text { for same stiffness as compared } \\
\text { cast iron bed. }\end{array}$ \\
\hline Jung Do Suh et al. & $10 \%$ Polyester Resin & $\begin{array}{l}60 \% \text { gravel and } \\
30 \% \text { sand }\end{array}$ & $\begin{array}{l}\text { damping factor is } 2.93 \%-5.69 \% \\
\text { larger than conventional structure } \\
\text { over wide range of frequency }\end{array}$ \\
\hline Tsung-Chia Chen et al. & - & - & $\begin{array}{l}\text { Dynamic stiffness of the granite } \\
\text { model was } 0.5-1.3 \text { times higher } \\
\text { than that of casting machine. }\end{array}$ \\
\hline $\begin{array}{l}\text { Prabhu Raja Venugopal } \\
\text { et al. }\end{array}$ & - & - & $\begin{array}{l}\text { Equivalent static stiffness and } \\
\text { natural frequencies of about } \\
\begin{array}{l}12-20 \% \\
\text { structure }\end{array}\end{array}$ \\
\hline
\end{tabular}

\section{RESULT ANALYSIS}

It has been observed that the mechanical properties of epoxy granite depend upon type and content of resin used. The epoxy resin shows better damping than polyester resin used for epoxy granite. It has been found that 10 to $15 \%$ of epoxy resin offers better damping of epoxy granite. The cost of epoxy granite is more than polyester granite as epoxy resin is more expensive than polyester resin. In future, the scope of research will be the reduction in amount of epoxy resin without any compromise in stiffness and damping.

The mechanical properties of epoxy granite depend upon type, proportions of aggregates used in epoxy granite. For same stiffness, the damping of epoxy granite is more than steel and cast iron with 40 to $50 \%$ mass reduction. The addition of steel reinforcements and welded steel structures with epoxy granite structures offer higher stiffness to structure and improved damping than epoxy granite structures. It has been found that as glass fibre content increases in epoxy granite increases damping ratio. As the glass fibres are more expensive than other fillers, its applicability is the main constrain. The use of Nelder-Mead minimization algorithm for curve fitting offers more consistent results than logarithmic decrement and half-power bandwidth methods.

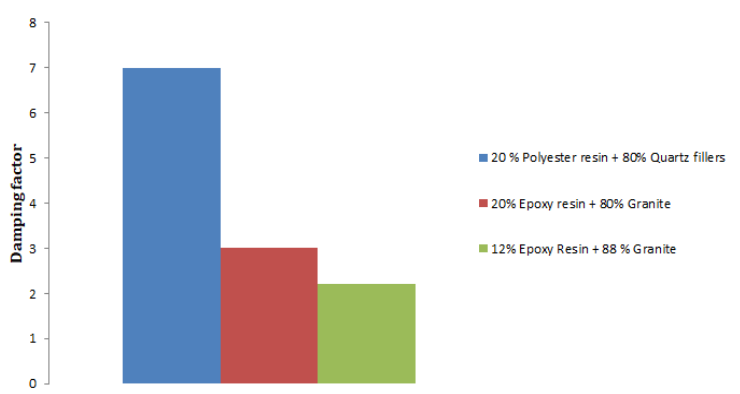

Fig. 2. Damping factor of Epoxy Granite

\section{CONCLUSION}

As the productivity and accuracy of machine tool became most significant, higher stiffness and damping of its structural material is essential. In this review work the various approaches towards improvement of stiffness and damping of epoxy granite are studied. The epoxy granite has proven that its damping and strength to weight ratio are superior to the conventional steel and cast iron structures. Therefore epoxy granite will be promoted as alternative structural material for machine tool. 


\section{Stiffness and Damping of Epoxy Granite}

\section{REFERENCES}

1. S. Orak, 2000, 'Investigation of vibration damping on polymer concrete with polyester resin,' Cement and Concrete Research, vol. 30, no.2, pp.171-174

2. Antonio Piratelli Filho, Flaminio Levi Nito, 2010, 'Behaviour of granite epoxy beams subjected to mechanical vibrations', Material s Research, 13(4), pp. 497-503

3. A. Selvakumar, P.V. Mohanram, 2012, 'Analysis of alternative composite material for high speed precision machine tool structures', Annals of faculty engineering Hunedoara- International journal of engineering,2,pp.95-98.

4. S. S. Balakrishna, H. Girish, G. C. Mohan Kumar, S. Narendranath, 2016, 'Analysis on Mechanical and Dynamic behavior of Granite Epoxy Composites with Cast Iron Particulates as Filler', Indian Journal of Advances in Chemical Science S1 (2016) 122-126

5. Wenfeng Bai , Jianhua Zhang, Peng Yan, Xinli Wang, 2008, 'Study on vibration alleviating properties of glass fiber reinforced polymer concrete through orthogonal tests', Materials \& Design, 30(4), $1417-1421$

6. Cortes F., \& Castillo G., 2006,'Comparison between the dynamical properties of polymer concrete and grey cast iron for machine tool applications' Materials \& Design, 28(5), 1461-1466.

7. Selvakumar, A., Ganesan, K., \& Mohanram, P., 2012, 'Dynamic analysis on fabricated mineral cast lathe bed', Proceedings of the Institution of Mechanical Engineers, Part B: Journal of Engineering Manufacture, 227(2), 261-266

8. Jung Do Suh, Dai Gil Lee, 2008, 'Design and manufacture of hybrid polymer concrete bed for high-speed CNC milling machine', International Journal of Mechanics and Materials in Design, 4, issue 2, pp. 113-121

9. Tsung-Chia Chen, Yong-Jun Chen, Ming-Hung Hung and Jui-Pin Hung, 2016, 'Design analysis of machine tool structure with artificial granite material', Advances in Mechanical Engineering, Vol. 8(7) 1-14

10. Venugopal, P. R., Kalayarasan, M., Thyla, P., Mohanram, P., Nataraj, M., Mohanraj, S., \& Sonawane, H., 2019, 'Structural investigation of steel-reinforced epoxy granite machine tool column by finite element analysis', Proceedings of the Institution of Mechanical Engineers, Part L: Journal of Materials: Design and Applications, Vol. 233(11) 2267-2279

\section{AUTHORS PROFILE}

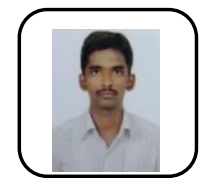

Mr. Deepak D. Ubale (M. Tech. in Design Engineering) is working as assistant professor in department of Mechanical Engineering at Dnyanshree institute of Engineering and Technology, Satara. His areas of interest are Vibration and Machine Design.

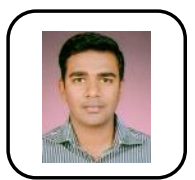

Mr. Raviraj V. Nimbalkar (M. Tech. in Production Engineering) is working as assistant professor in department of Mechanical Engineering at Dnyanshree institute of Engineering and Technology, Satara.

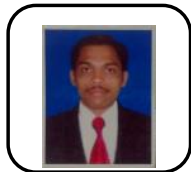

Mr. Vivek R. Chavan (M. E. in Production Engineering) is working as assistant professor in department of Mechanical Engineering at Dnyanshree institute of Engineering and Technology, Satara 